PERM JOURNAL OF PETROLEUM AND MINING ENGINEERING ВЕСТНИК ПНИПУ. ГЕОЛОГИЯ. НЕФТЕТАЗОВОЕ И ГОРНОЕ ДЕЛО ISSN 2224-9923 Volume/ Tom 19 №4 2019

http://vestnik pstu.ru/geo/

UDC 622.276+669.054.8:658.567.1

Article / Статья

(C) PNRPU / ПНИПУ, 2019

\title{
THE EFFECTIVE METHOD FOR HYDROVORTEX CLASSIFICATION OF FINELY DISPERSED TECHNOGENIC MINERAL WASTE IN THE MINING AND METALS INDUSTRY
}

\section{N.P. Kosarev, V.N. Makarov, A.V. Ugolnikov, N.V. Makarov, A.V. Lifanov ${ }^{1}$}

Ural State Mining University (30 Kuybysheva st., Yekaterinburg, 620144, Russian Federation)

${ }^{1}$ Scientific-Production Complex "OylGazMash" (2D Zheleznodorozhnaya st., Podolsk, 142103, Russian Federation)

\section{ЭФФЕКТИВНЫЙ СПОСОБ ГИДРОВИХРЕВОЙ КЛАССИФИКАЦИИ ТОНКОДИСПЕРСНЫХ ТЕХНОГЕННЫХ МИНЕРАЛЬНЫХ ОТХОДОВ В ГОРНО-МЕТАЛЛУРГИЧЕСКОМ КОМПЛЕКСЕ}

\section{Н.П. Косарев, В.Н. Макаров, А.В. Угольников, Н.В. Макаров, А.В. Лифанов ${ }^{1}$}

Уральский государственный горный университет (620144, Россия, г. Екатеринбург, ул. Куйбышева, 30)

${ }^{1}$ Научно-производственный комплекс «ОйлГазМаш» (142103, Россия, г. Подольск, ул. Железнодорожная, 2Д)

Received / Получена: 10.06.2019. Accepted / Принята: 01.11.2019. Published / Опубликована: 27.12.2019

Key words:

recycling, classification,

hydrovortex heterocoagulation,

Venturi pipe, Reynolds and Eule

criteria, supra-Stokes motion.

\begin{abstract}
The paper describes the development of an effective method and technology for hydrovortex classification of technogenic mineral formation (TMF) nanoparticles in a fluidized bed. In addition, it deals with designing a mathematical apparatus to calculate the geometry and energy characteristics necessary to implement the method. Numerous studies have shown that effective recycling of technogenic mineral formations is limited by stringent requirements to fractional composition, median size and dispersity of TMF particles. Insufficiently advanced equipment, technology and TMF classification restrain the ability to use the TMF. The rigid requirements to the TMF classification by median size dispersion necessitate searching for the methods and technical aids, which would allow for meeting these requirements in the conditions of probabilistic distribution of physical and mechanical, geometrical, and kinematic parameters of the microparticles. The mathematical model for the hydrovortex classification of TMF micro and nanoparticles has been built using the Boussinesq hydrodynamic equations and dimension theory. The motion equations for a 'liquid drop - TMF microparticle' dispersed system have been obtained in the conditions of unsteady hydrodynamic inertial supra-Stokes drop - TMF microparticle' dispersed system have been obtained in the conditions of unsteady hydrodynamic inertial supra-Stokes
motion during the classification, as a function of the Euler and Reynolds criteria. It has been confirmed that the diameter of the motion during the classification, as a function of the Euler and Reynolds criteria. It has been confirmed that the diameter of the
completely absorbed particles comprising free-flowing TMF components depends on the liquid drop rotation rate in the hydrovortex classification. It has been established that, in the hydrovortex classification, the relaxation time of liquid drops with integrated TMF micro and nanoparticles depends on the particle median size. Based on the required performance and energy characteristics of a hydrovortex aerator, we obtained an equation for calculating geometric parameters of a Venturi classifier. Feasibility of separating TMF microparticles in the range of $(0.5-5.0) 10^{-6}$ with a dispersion of maximum $20 \%$ was confirmed by testing a pilot industrial TMF microparticles in the range of $(0.5-5.0) 10^{-6}$ with a dispersion of maximum
model of the Venturi GKV-200 hydrovortex classifier in a certification procedure.
\end{abstract}

Освещены создание эффективного способа и технологии гидровихревой классификации в кипящем слое наночастиц техногенных минеральных образований (TMO) и разработка математического аппарата для расчета его геометрических и энергетических характеристик. Многочисленные исследования показывают, что эффективность утилизации техногенных минеральных образований ограничена высокими требованиями к фракционному составу, медианным размерам и дисперсности их частиц. Сдерживающим фактором использования ТМО является недостаточное совершенство техники и технологии и их классификации. Жесткие требования классификации по недостаточное совершенство техники и технологии и их классификации. Жесткие требования классификации по
дисперсии медианных размеров ТМО обусловливают необходимость поиска способов и технических средств их реализации, которые в условиях вероятностного распределения физико-механических, геометрических, кинематических параметров микрочастиц могут эффективно их реализовывать. С использованием гидродинамических уравнений Буссинеска и теории размерностей построена математическая модель гидровихревой классификации микро- и наночастиц ТМО. Получены уравней движения дисперсной системы капля жидкости - микрочастица TMO» в условия неустановившегося гидродинамического инерционного надстоксовского движения в процессе классификации в функции критериев Эйлера и Рейнольдса. Подтверждена зависимость диаметра полностью поглощаемых частиц компонентов сыпучих ТМО от угловой скорости вращения капель жидкости в процессе гидровихревой классификации. Установлено, что время релаксации капель жидкости с интегрированными в них микро- и наночастицами ТМО в процессе гидровихревой классификации зависит от их медианного размера. Получено уравнение для расчета геометрических параметров классификатора Вентури от потребной производительности и энергетических характеристик гидровихревого аэратора. Сертификационные испытания опытно-промышленного образца гидровихревого классификатора Вентури ГКВ-200 подтвердили возможность разделения микрочастиц ТМО в диапазоне $(0,5-5,0) 10^{-6}$ с дисперсией не более $20 \%$.

Nikolay P. Kosarev (Author ID in Scopus: 6602443934) - Doctor of Engineering, Professor (tel.: +007 343 295 13 05, e-mail: ursmu@bk.ru).

Vladimir N. Makarov (Author ID in Scopus: 56682510900) - Doctor of Engineering, Professor of the Department of Mining Mechanics (tel.: +007 3432950448 , e-mail: uk.intelnedra@gmail.com).

Aleksandr V. Ugolnikov (Author ID in Scopus: 57206674668) - PhD in Engineering, Associate Professor, Head of the Department of Electrical Engineering (tel.: +007 343 283 0372, e-mail: ugolnikov@yandex.ru). The contact person for correspondence.

Nikolay V. Makarov (Author ID in Scopus: 57196121902 ) - PhD in Engineering, Associate Professor, Head of the Department of Mining Mechanics (tel.: +007 343 257 4542, e-mail: mnikolay84@mail.ru).

Aleksandr V. Lifanov (Author ID in Scopus: 57211516049) - General Director (tel.: +007 49550566 97, e-mail: info@oilgazmash.ru).

Косарев Николай Петрович - доктор технических наук, профессор (тел.: +007 34329513 05, e-mail: ursmu@bk.ru)

Макаров Владимир Николаевич - доктор технических наук, профессор кафедры горной механики (тел.: +007 343 295 04 48, e-mail: uk.intelnedra@gmail.com). Угольников Александр Владимирович - кандидат технических наук, доцент, заведующий кафедрой электротехники (тел.: +007 343 283 03 72, e-mail: ugolnikov@уandex.ru). Контактное лицо для переписки.

Макаров Николай Владимирович - кандидат технических наук, доцент, заведующий кафедрой горной механики (тел.: +007 343 257 45 42, e-mail: mnikolay84@mail.ru). Лифанов Александр Викторович - генеральный директор (тел.: +007 49550566 97, e-mail: info@oilgazmash.ru). 


\section{Introduction}

Competitiveness of the Russian mining and metals industry is based on adoption of state-ofthe-art hi-tech equipment for manufacturing products and materials with unique functional properties. To a large extent, it concerns technological preparation and classification of source raw materials. These processes significantly influence finished product quality.

One way to improve the classification effectiveness is to design less energy intensive separation devices and to improve the structure and technology of preparing and separating source raw materials [1-5].

Nanoparticles as modifying additives and as individual materials reveal some new opportunities. For instance, the method of using nanopowders to obtain a new set of functional properties has no alternatives in production of hard-melting dispersereinforced composite materials [6-10].

The return nano-containing alumina dust in this instance is recirculating ballast with a weight fraction of $7-14 \%$ of the total amount of the produced alumina. Taking into account that the annual production volume of alumina in the Russian Federation is estimated as 11.5 million tons, the recirculating alumina dust makes up a substantial volume $[7,11,12]$.

In the course of commercial alumina manufacturing, the nano-containing alumina dust collected in gas cleaning plants is subjected to intensive thermal treatment and mechanical impact. From this point of view, the alumina dust can also be considered as a commercial product with a certain consumer value. Consequently, development of rational methods for using the alumina dust can have practical benefits [13-20].

The market of composite materials and alloys is not less important, as manufacturing of these products need the alloying materials that also have to meet stringent requirements in terms of median size and dispersion. According to the forecast, the annual demand for the composite materials widely used in the Russian mining and metals industry will grow at least $8 \%$ until 2025. However, their quality directly depends on the quality of their ingredients, alloying additives and first of all their fractional composition dispersion [21-28].

A considerable drawback of these classification means is their poor ability to form an effective narrow range of collectible micro and nanoparticle fractions.

\section{Object and methods of research}

To design a mathematical model for hydrovortex classification of the TMF component particles by fractions with a predetermined dispersion, the authors used a tabular analytic model for hydrovortex inertial orthokinetic heterocoagulation. This model was proposed in $[29,30]$ and confirmed significant difference in the interaction mechanism of a solid particle and a liquid drop in the collision process. Moreover, the model proved the impact of a liquid drop rotation rate on kinematic parameters of the interaction and energy characteristics.

The research hypothesis stated a direct correlation between minimum diameter of completely absorbed solid particles and rotation rate of liquid drops during the hydrovortex inertial kinematic heterocoagulation. This hypothesis was mathematically and experimentally confirmed for completely hydrophobic particles such as nanoparticles, including the TMF with particle diameter of $6 \cdot 10^{6} \mathrm{~m}$. Along with that, physical, mechanical and chemical properties of the particles do not influence the wetting result within the diameters of the absorbed solid particles $d_{\mathrm{p} \omega \min } \leq d_{\mathrm{p}} \leq$ $d_{\mathrm{p} \text { min }}$, i.e. at such kinetic energy when the translational motion of liquid drops exceeds the aerodynamic barrier threshold [31].

Taking into account the papers [32-36], an equation for minimum diameter of the absorbed hydrophobic particle can be presented as

$$
\begin{gathered}
d_{\mathrm{p} \omega \min }=24 \frac{\delta_{1-\mathrm{g}}}{\left(\rho_{\mathrm{p}}-\rho_{\mathrm{g}}\right) V_{1}^{2}} \times \\
\times\left(\cos \theta \sqrt{1-K_{\omega}^{2} \cdot \omega_{1}^{4}}-\sin \theta \cdot K_{\omega}^{2} \cdot \omega_{1}^{2}\right),
\end{gathered}
$$

where $d_{\mathrm{p} \text { min }}$ - minimum diameter of the absorbed solid particle in the classical coagulation condition at $\omega_{1}=0$, $\mathrm{m} ; \rho_{\mathrm{p}}, \rho_{\mathrm{g}}-$ particle density and gas density, respectively, $\mathrm{kg} / \mathrm{m}^{3} ; V_{\mathrm{l}}, V_{\mathrm{g}}=V_{\mathrm{p}}-$ liquid drop velocity and gas velocity equal to the particle velocity, $\mathrm{m} / \mathrm{s} ; \delta_{1-\mathrm{g}}$ - surface tension coefficient at the liquid-gas interface, $\mathrm{J} / \mathrm{m}^{2}$; $\theta$ - contact wetting angle at the liquid-gas interface, rad; $K_{\omega}=\frac{\pi \rho_{l} d_{\mathrm{p} \text { min }}^{3} \sin ^{4} \theta}{8 \delta_{1-\mathrm{g}} \cos \theta} ; \rho_{1}-$ liquid drop density, $\mathrm{kg} / \mathrm{m}^{3}$. 
Based on the results of the experimental studies, relative rotation rate of a liquid drop is $K_{\omega} \leq \omega^{2} \leq 0.3$.

The critical diameter variation coefficient for the absorbed TMF nanoparticles from the rotation rate of liquid drops to the minimum diameter variation of completely absorbed nanoparticles is obtained as

$$
\begin{gathered}
K_{\omega}^{d}=48 \frac{\delta_{1-\mathrm{g}}}{\left(\rho_{\mathrm{p}}-\rho_{\mathrm{g}}\right) V_{1}^{2}} \times \\
\times K_{\omega}^{2} \cos \theta\left(\omega_{1}^{3}-K_{\omega}^{2} \cdot \omega_{1}^{7}\right)-K_{\omega} \cdot \sin \theta \cdot \omega_{1} .
\end{gathered}
$$

Figure 1 shows a dependency curve of the critical diameter variation coefficient for the absorbed TMF nanoparticles with various wetting angles on the rotation rate during the hydrovortex coagulation.

An analysis of the curves shown in Figure 1 suggests that an increase in the rotation rate of liquid drops across the entire considered range of the minimum diameter variation coefficient for the component particles from the rotation rate during the hydrovortex heterocoagulation, the $K_{\omega}^{d}$ has a negative value. This means that the hydrovortex heterocoagulation reduces the diameter of completely absorbed component particles, whereas the derivative from $K_{\omega}^{d}$ decreases as $\omega$ grows. The monotony and equivalence of the variation coefficient $K_{\omega}^{d}$ dynamics pattern for various TMF components confirm the hypothesis about correlation of the minimum absorbed particle diameter with the liquid drop rotation rate during the hydrovortex coagulation. Along with that, the liquid drop rotation rate more effectively reduce the minimum diameter of the absorbed particles, when the specific energy of TMF particle surface tension is the less, in other words, when the contact wetting angle is larger.

In order to solve the practical task of TMF nanoparticles recycling, the paper proposes a universal device for hydrovortex classification, enabling nanoparticles separation into fractions by their predetermined median size and dispersion.

By design, the Venturi hydrovortex classifier includes a pneumatic pipeline for vertical transportation of the TMF free-flowing particles and a device for hydrovortex separation of the particles into fractions by way of their inertial heterocoagulation with rotating liquid drops. The device consists of a Venturi pipe and an aerator with vortex nozzles. The aerator is installed on the pipe axis in the critical section. On the pipe perimeter there is a receiving ring bin.

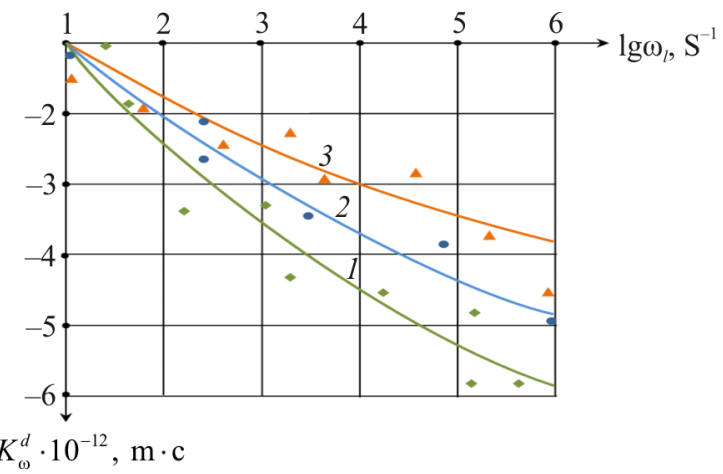

Fig. 1. The dependency of the minimum diameter variation coefficient for the absorbed component particles on the rotation rate during the hydrovortex heterocoagulation: 1 - coal, 2 - silicone oxide, 3 - alumina

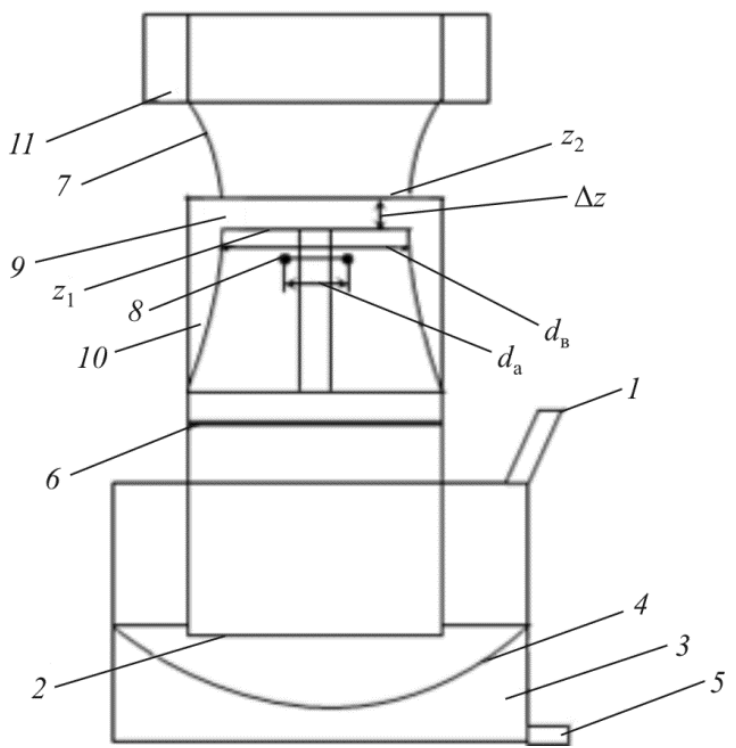

Fig. 2. Basic scheme of the Venturi hydrovortex classifier

Figure 2 shows a basic diagram of the Venturi hydrovortex classifier.

The Venturi classifier includes intake feeder 1 installed above collector 2 of the classifier. Mixing chamber 3 accommodates a porous gas distribution partition 4 and pipe branch 5 supplying compressed air and forming a fluidized bed of free-flowing TMF material on the input to collector 2. Immediately before the input to Venturi pipe 7, there is a honeycomb to even the velocity of the free-flowing material particles across the entire section of the pneumatic pipeline. Hydrovortex aerator with nozzles 8 is located in the critical section of the 
Venturi pipe, along its axis. The hydrovortex aerator perimeter is fitted with classification collector 9 with bins 10 for collection of TMF component particles by fractions. The Venturi pipe discharge is equipped with bin 11 for waste particles, which size does not fit the classification parameters.

The Venturi classifier operates as follows. Feeder 1 continuously deliver the free-flowing TMF particles into mixing chamber 3 . Pipe branch 5 and porous gas distribution partition 4 supply the compressed gas below the TMF bed. The free-flowing material is aerated by the compressed gas to the fluidized-bed condition and is then fed via input collector 2 and through evening honeycomb 6 to Venturi pipe 7 inlet. Liquid drops swirled on themselves in the hydrovortex nozzles of aerator 8 wet the fluidized free-flowing material. Kinematic energy and rotation rate of the liquid drops ensure guaranteed coagulation of the TMF particles with the predetermined minimum diameter.

The aerator diameter $d_{\mathrm{a}}$, Venturi pipe diameter (in the critical section) $d_{\mathrm{B}}$ and liquid drop energy are selected the way to enable the coagulation of liquid drops and TMF particles with the predetermined minimum median diameter in a zone up to $80 \%$ of the Venturi pipe diameter. This way, in the perimeter ring zone occupying $20 \%$ of the Venturi pipe diameter, the fluidized TMF component particles rise to the waste bin. They are not being wetted the liquid drop energy is insufficient to overcome the aerodynamic energy barrier. This is necessary to ensure guaranteed effectiveness of the particle classification by fractions with the predetermined dispersion, as the unsteady coagulation zone near the entrance to the classification bin is excluded from the classification process. Being calculated according to the proposed mathematical model, the trajectories of liquid drops with integrated TMF particles in the inertial hydrovortex heterocoagulation process determine the position of classification collector 9 and classification bin 0 in regard to the plane of hydrovortex aerator 8 nozzles.

The TMF nanoparticle trajectory is determined by the inertial interaction between nanoparticles, rotating liquid drops and fluidized bed energy flow.

\section{Research findings}

In order to build a mathematical model of the unsteady hydrodynamic interaction between a liquid drop and component particles in conditions of high
Reynolds numbers, let us assume that in its motion a liquid drop preserves spherical shape $d_{1}$ with a density of the drop liquid. In addition, the drop aerodynamic characteristic of motion in gas corresponds to the actual characteristic of the drop motion at the same Reynolds numbers. Diameter $d_{1}$ of the assumed spherical particle will be considered the aerodynamic diameter of the drop.

Taking into account the proposed hypothesis, to ensure a unique and definite solution, let us assume a condition at which the energy of the liquid drop translation motion is sufficient to overcome the aerodynamic energy barrier across the entire fluidized bed of the TMF alloying component particles. In other words, $S t k_{\mathrm{c}} \geqslant S t k_{\mathrm{cr}}$ in the fluidized bed diameter of maximum $80 \%$ of the Venturi classifier diameter, in particular the diameter of the classification bin inlet. Thus, in the perimeter ring zone occupying $20 \%$ of the Venturi pipe diameter, the fluidized TMF particles rise to the waste bin. They are not being wetted the liquid drop energy is insufficient to overcome the aerodynamic energy barrier.

Taking into account homogeneous distribution of the component nanoparticles in the fluidized bed, the discreteness of identical particle trajectories will be determined by the particle absorption in end points of the Venturi pipe, i.e. along the perimeters of aerator diameter $d_{\mathrm{a}}$ and diameter $d=0.8 d_{\mathrm{V}}$. Taking into account the proposed hypothesis, in order to build a system of equations for the nanoparticle motion, let us introduce the notions of reduced aerodynamic diameter and reduced nanoparticle density and let us present them as [31]

$$
d_{\Sigma}=\frac{6 \cdot \sqrt[3]{\frac{\pi}{6}\left(d_{1}^{3}+d_{\mathrm{p}}^{3}\right)}}{\pi} ; \rho_{\Sigma}=\frac{d_{1}^{3} \cdot \rho_{1}+d_{\mathrm{p}}^{3} \cdot \rho_{\mathrm{p}}}{d_{1}^{3}+d_{\mathrm{p}}^{3}} .
$$

According to the classical Newton equation, the motion equation for the $i$ th particle given its complete absorption by a liquid drop as projected to axis $0 r$, in the plane of hydrovortex aerator nozzles, can be put down as [37]

$$
m_{i} \frac{\partial V_{r i}}{\partial t}=F_{r i},
$$

where $F_{r i}-$ drag force of the TMF particle motion in the Venturi classifier, $F_{r i}=k_{i} \frac{\pi}{4} d_{\Sigma i}^{2} \rho_{\mathrm{g}} \cdot V_{\Sigma i}^{2} ; k_{i}-i$ th particle drag coefficient; $d_{\Sigma i}-i$ th particle diameter, $\mathrm{m}$; $\rho_{\mathrm{g}}-$ gas density, $\mathrm{kg} / \mathrm{m}^{3} ; V_{\Sigma i}-i$ th particle velocity, $\mathrm{m} / \mathrm{s}$. 
The $i$ th particle motion equation as projected to axis $0 z$ is presented as

$$
m_{i} \frac{\partial V_{z i}}{\partial t}=-F_{A i}-F_{S i}+F_{P i}
$$

where $F_{A i}$ - Archimedes force directed downwards and effecting the $i$ th particle, being an analog to the force of gravity, $F_{A i}=\frac{1}{6} \pi d_{\Sigma i}^{3}\left(\rho_{\Sigma i}-\rho_{\mathrm{g}}\right) g$; $F_{S i}$ - Stokes drag force caused by air viscosity and physical properties of the source raw material, $F_{S i}=\frac{\varphi}{2} \mu_{\mathrm{g}} \pi d_{\Sigma i} V_{z i} ; \quad F_{\mathrm{P} i}-$ pressure force of the fluidizing air, $F_{\mathrm{P} i}=C_{c} \rho_{\mathrm{g}} V_{\mathrm{g} i}^{2} \frac{\pi}{4} d_{\Sigma i}^{2} ; C_{f i}$ - pressure force coefficient of the fluidizing air, affecting the $i$ th particle; $V_{\mathrm{g}}, V_{z i}$ - fluidizing air velocity, and vertical component of the $i$ th particle velocity, $\mathrm{m} / \mathrm{s}$; $g-$ acceleration of gravity, $\mathrm{m} / \mathrm{s}^{2} ; \varphi_{i}-$ particle drag coefficient in Stokes law; $\mu-$ air dynamic viscosity coefficient, $\mathrm{kg} / \mathrm{ms}$.

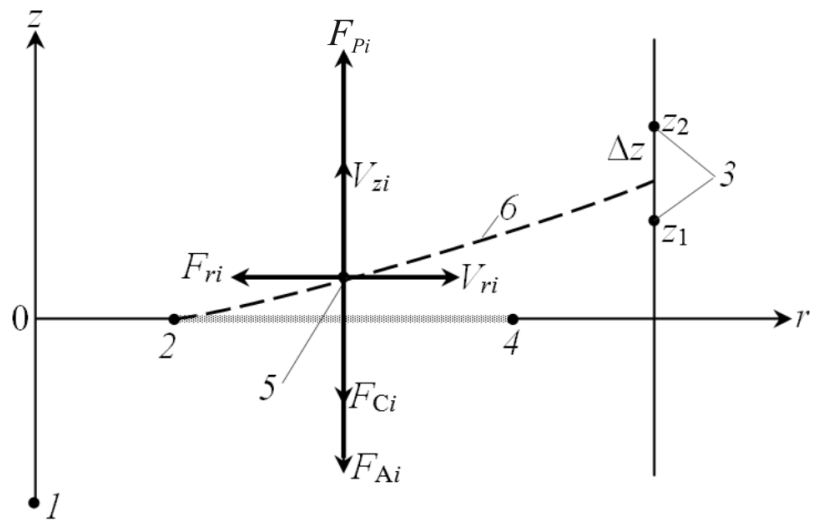

Fig. 3. Basic diagram for liquid drop motion with integrated TMF particle and forces effecting it in conditions of hydrovortex classification: 1 - Venturi classifier axis; 2 - location coordinate of hydrovortex aerator nozzle; 3 - lower and upper boundary coordinates of the classification collector; 4 - fluidized bed plane; 5 - liquid drop with integrated TMF particle; 6 - motion trajectory of the liquid drop with integrated TMF particle

Thus, the vertical motion equation as projected to axis $0 z$ for the $i$ th particle of the source raw material components under the effect of a controlled directional air flow, taking into account the effects of Stokes and Archimedes forces and pressure force of the fluidizing air, can be presented as

$$
V_{z i}=\frac{\frac{1}{2} C_{c} \rho_{\mathrm{g}} V_{\mathrm{g} i}^{2} d_{\Sigma i}-\frac{1}{3} d_{\Sigma i}^{2}\left(\rho_{\Sigma i}-\rho_{\mathrm{g}}\right) g}{\varphi \cdot \mu_{\mathrm{g}}} .
$$

Equation (4) is a hydrodynamically unsteady behavior equation describing the inertial movement of a liquid drop before and after the TMF nanoparticle coagulation.

$$
\frac{\partial V_{r i}}{\partial t}=\frac{V_{r i}}{\tau_{p i}}
$$

where $\tau_{\mathrm{p} i}=\tau_{\Sigma i}=k_{i} \frac{2+3 \bar{\mu}}{3+3 \bar{\mu}} \cdot \frac{d_{\Sigma i}^{2}\left(\rho_{\Sigma i}-\rho_{\mathrm{g}}\right)}{18 \mu_{\mathrm{g}}} ; \bar{\mu}=\frac{\mu_{1}}{\mu_{\mathrm{g}}}$.

The Boussinesq equation helps determine the relaxation time for both a liquid drop and of a nanoparticle, and relates it to the drag coefficient. The drag coefficient in the Boussinesq equation corresponds to $k_{i}$ in equation (4).

Until present, numerous studies of coagulation interaction between component particles and liquid drops have been unable to fully resolve the absorption mechanism. An effective method for this process control has not been developed so far. Due to this reason, the aerohydrodynamic behavior of the unsteady inertial interaction between liquid drops and solid particles in the supra-Stokes region, i.e. at $\mathrm{Re}>$ 1 , in the dynamically active region of high-pressure liquid atomization, require serious theoretical and experimental research in part of relation and mutual influence of the inertial and viscous drag forces. The dynamically active area of coagulation interaction between liquid drops and component particles manifests continuous, and, most importantly, significant variation of Reynolds and Euler numbers from values exceeding $10^{4}$, to values less than 1 in the area of their inertial path in the gas medium. Experimental research has shown that the drag force grows highly unlinearly with the growth of Reynolds number in the area of supra-Stokes motion, contrary to its linear growth at numbers $\operatorname{Re}<1$ and at simultaneous reduction of relaxation time $\tau$. This significantly complicates finding its actual value, and thus impedes using the classical Stokes motion equations for the coagulation $[31,38]$.

Since the drag coefficient of liquid drop in gas medium $k_{i}$ is the significant variable in equation (4) of the liquid drop aerohydrodynamic behavior in the horizontal plane of the Venturi classifier, let us calculate its dependency on the physical values 
describing the hydrodynamic process of the liquid drop inertial motion under the effect of acceleration with the initial velocity $V_{0}$, in form of a dimensionless simplex in conditions of steady motion.

The dependency equation of $k_{i}$ coefficient on independent variables in form of a dimensionless power law can be expressed as [39]

$$
\begin{aligned}
k_{i}=C & \cdot \mu_{\mathrm{g}}^{\alpha} \cdot \rho_{\mathrm{g}}^{\beta} \sqrt{V_{r i}^{2}+0,25 d_{\Sigma i}^{2} \sin \theta^{2} \cdot \omega_{1}^{2}} \gamma \\
\times & d_{\Sigma i}^{\varepsilon} \cdot\left(\frac{\partial V_{r i}}{\partial t} \cdot \frac{\rho_{1}-\rho_{\mathrm{r}}}{\rho_{\mathrm{g}}}\right)^{\varphi} \cdot V_{0}^{\psi} .
\end{aligned}
$$

To determine similarity indicators, let us use a dimension independent matrix with a rank of three [39].

Taking into account the system of homogenous linear equations made of equation power indexes (8), the similarity indicator matrix will appear as follows

\begin{tabular}{c|c|c|c|c|c|c} 
& $\mu_{\mathrm{g}}$ & $\rho_{\mathrm{r}}$ & $\sqrt{V_{1}^{2}+0,25 \omega^{2} \cdot d_{\mathrm{cM}}^{2}}$ & $d_{1}$ & $\frac{\partial V_{r i}}{\partial t} \cdot \frac{\rho_{1}-\rho_{\mathrm{g}}}{\rho_{\mathrm{g}}}$ & $V_{0}$ \\
\hline$\pi_{1}$ & -2 & 2 & 2 & 2 & 0 & 0 \\
\hline$\pi_{2}$ & 0 & 0 & 0 & 1 & 1 & -2 \\
\hline$\pi_{3}$ & -2 & 2 & 0 & 2 & 0 & +2 \\
\hline
\end{tabular}

Expanding the matrix determinants (9), we obtain three similarity indicators of steady aerohydrodynamic motion for the liquid drop in gas medium at high Reynolds numbers.

$$
\begin{gathered}
\pi_{1}=\frac{\rho_{\mathrm{g}}^{2}\left(V_{1 i}^{2}+0,25 \omega_{1 i}^{2} \cdot d_{\mathrm{cm} i}^{2}\right) d_{1 i}^{2}}{\mu_{\mathrm{g}}^{2}}=\operatorname{Re}_{1 \omega i}^{2} ; \\
\pi_{2}=\frac{P_{i}}{\rho_{\mathrm{g}} \cdot V_{0 i}^{2}}=\frac{\frac{\partial V_{r i}}{\partial t} \cdot d_{1 i}\left(\rho_{1}-\rho_{\mathrm{g}}\right)}{\rho_{\mathrm{g}} \cdot V_{0 i}^{2}}=\mathrm{Eu}_{i} ; \\
\pi_{3}=\frac{\rho_{\mathrm{g}}^{2} V_{0 i}^{2} d_{1 i}^{2}}{\mu_{\mathrm{g}}^{2}}=\operatorname{Re}_{10 i}^{2} .
\end{gathered}
$$

Thus, equation (8) in criterial form will look like

$$
k_{i}=C \cdot\left(\operatorname{Re}_{1 \omega i}^{2}\right)^{a} \cdot \mathrm{Eu}_{i}^{b} \cdot\left(\operatorname{Re}_{10 i}^{2}\right)^{c} .
$$

The numerical values of proportionality coefficient $C$ and power indexes $a, b, c$ in equation (13) shall be determined from the equation of steady motion that describes the liquid drop in gas medium:

$$
\frac{m_{i} \partial V_{r i}}{\partial t}=\mathrm{Eu}_{i} \cdot \rho_{\mathrm{g}} \cdot V_{0 i}^{2} \frac{\pi d_{\Sigma i}^{2}}{4} .
$$

Taking into account the aforementioned, we obtain an equation relating Euler, Reynolds criteria and aerodynamic drag coefficient $k_{i}$ for the liquid drop motion in gas medium:

$$
k_{i}=\frac{2}{3} \cdot \frac{\mathrm{Eu}_{i}}{\operatorname{Re}_{1 \omega i}^{2} \cdot \operatorname{Re}_{10 i}^{2}} .
$$

After transformations with respect to Reynolds number, the equation to determine the relaxation time of a 'liquid drop - TMF microparticle' disperse system will appear as

$$
\tau_{\mathrm{c} i}=\frac{2}{9} \cdot \frac{d_{\Sigma i}^{2}\left(\rho_{\Sigma i}-\rho_{\mathrm{g}}\right) \mathrm{Re}_{0 i}^{2}}{\mathrm{Eu}_{i} \cdot \mu_{\mathrm{g}} \cdot \operatorname{Re}_{1 i}^{2}} .
$$

Taking into account that Reynolds and Euler criteria are functionally related, and, most importantly, continuously and significantly change along the liquid drop inertial path in conditions of supra-Stokes motion, let us consider a possibility to solve the task by averaging the kinematic parameters. The classical hydrodynamic motion theory in steady conditions can help obtain quadrature expressions for the time of liquid drop and component particle relaxation depending on the kinematic flow parameters. In works [31, 38] the expression was obtained for the relaxation time variation at high Reynolds numbers by way of averaging their values.

Taking into account the aforementioned, the expression for average drag coefficient value in equation (4) will appear as:

$$
k_{\mathrm{cp} i}=\frac{72}{\operatorname{Re}_{0 i}}\left(1+0,07_{0 i}^{0,687}\right) \text {. }
$$

After the necessary transformations, the expression for average relaxation time of a 'liquid drop - TMF microparticle' disperse system will appear as

$$
\tau_{\Sigma \mathrm{cp} i}=4 d_{\Sigma i}^{2} \frac{\left(\rho_{\Sigma i}-\rho_{\mathrm{g}}\right)\left(1+0,07_{0 i}^{0,687}\right)(3+3 \bar{\mu})}{\operatorname{Re}_{0 i} \cdot(2+3 \bar{\mu}) \mu_{\mathrm{g}}} .
$$

Equation (18) suggests that average relaxation time of liquid drops with integrated TMF paarticles is a function of the liquid drop squared diameter. This can be used to develop a technology for effective classification of the finely dispersed free-flowing TMF.

The proposed model for staged averaging of the relaxation time and liquid drop drag coefficients in gas medium provides reasonable accuracy for using 
the classical aerohydrodynamic equation of the liquid drop steady motion in the range of Reynolds numbers to $10^{4}$ at the length of free inertial path of the liquid drops in gas medium.

Taking into account the mathematical model proposed in [30], an equation for calculating the Venturi classifier diameter in the critical section, where the input classification collector and hydrovortex aerator nozzles are positioned, will appear as

$$
d_{\mathrm{y}}=2\left(V_{0}-1,6 \sqrt{\frac{3}{2} \cdot \frac{\delta_{l-g} \cos \theta}{\rho \Sigma d \Sigma m}}\right) \tau_{\Sigma \mathrm{cp}}+d_{\mathrm{a}} .
$$

Provided that the terms of reference for the Venturi hydrovortex classifier stipulate a requirement for the recycling performance identified by mass of the TMF free-flowing materials $Q, \mathrm{t} / \mathrm{h}$, the design determinant will be the liquid drop velocity on exit from the hydrovortex aerator nozzles $V_{0}$.

In this case, the Venturi classifier diameter $d_{v}$ is determined by formula

$$
d_{\mathrm{y}}=2 \sqrt{\frac{Q}{\pi \rho_{\mathrm{c}} V_{z}}}
$$

whereas the liquid drop velocity on exit from the hydrovortex aerator nozzles when the classification procedure is active, describes energy parameters, and can be found using an expression

$$
V_{0}=3,2 \sqrt{\frac{3}{2} \cdot \frac{\delta_{1-\mathrm{g}} \cos \theta}{\rho \Sigma d \Sigma m}}+\frac{d_{\mathrm{y}}-d_{\mathrm{a}}}{\tau_{\Sigma \mathrm{cp}}} .
$$

The coordinates of input classification collector with bins for collecting TMF particles with the predefined parameters of median diameter and its dispersion $d_{m}, \sigma_{m}$ for the upper and lower boundaries can be calculated using the formulas

$$
\begin{gathered}
z_{2}=\tau_{\Sigma c \mathrm{pmin}} \times\left(\frac{1}{2} C_{c} \rho_{\mathrm{g}} V_{\mathrm{g}}^{2} d_{\Sigma \min }-\frac{1}{3}\left(\rho_{\Sigma \min }-\rho_{\mathrm{g}}\right) \times\right. \\
\times g \cdot d_{\Sigma \min }^{2}-5 \cdot 10^{-4} \omega_{0} \cdot \omega_{a} \cdot \rho_{1} \cdot \rho_{\Sigma \min }^{-1} \cdot d_{4 \min }^{5} \times \\
\left.\times d_{\Sigma \min }^{-3}\left(1+\frac{d_{\mathrm{a}}}{d_{\mathrm{K}}}\right)\right) /\left(\varphi \mu_{\mathrm{g}} \ln \frac{V_{0}}{\sqrt{6 \cdot \delta_{1-\mathrm{g}} \cos \theta \rho_{\Sigma \min }^{-1} d_{\Sigma \min }^{-1}}}\right) ; \\
z_{1}=\tau_{\Sigma \mathrm{cpmmax}}\left(C_{c} \rho_{\mathrm{g}} V_{\mathrm{g}}^{2} d_{\Sigma \max }-\frac{2}{3}\left(\rho_{\Sigma \max }-\rho_{\mathrm{g}}\right) g \times\right. \\
\times d_{\Sigma \max }^{2}-5 \cdot 10^{-4} \omega_{\mathrm{o}} \cdot \omega_{a} \cdot \rho_{1} \cdot \rho_{\Sigma \max }^{-1} \cdot d_{4 \max }^{5} \times \\
\left.\times d_{\Sigma \max }^{-3}\left(1+\frac{d_{\mathrm{a}}}{d_{\mathrm{K}}}\right)\right) /\left(10 \varphi \mu_{\mathrm{g}} \ln \frac{V_{0}}{\sqrt{6 \cdot \delta_{1-\mathrm{g}} \cos \theta \rho_{\Sigma \max }^{-1} d_{\Sigma \max }^{-1}}}\right) .
\end{gathered}
$$
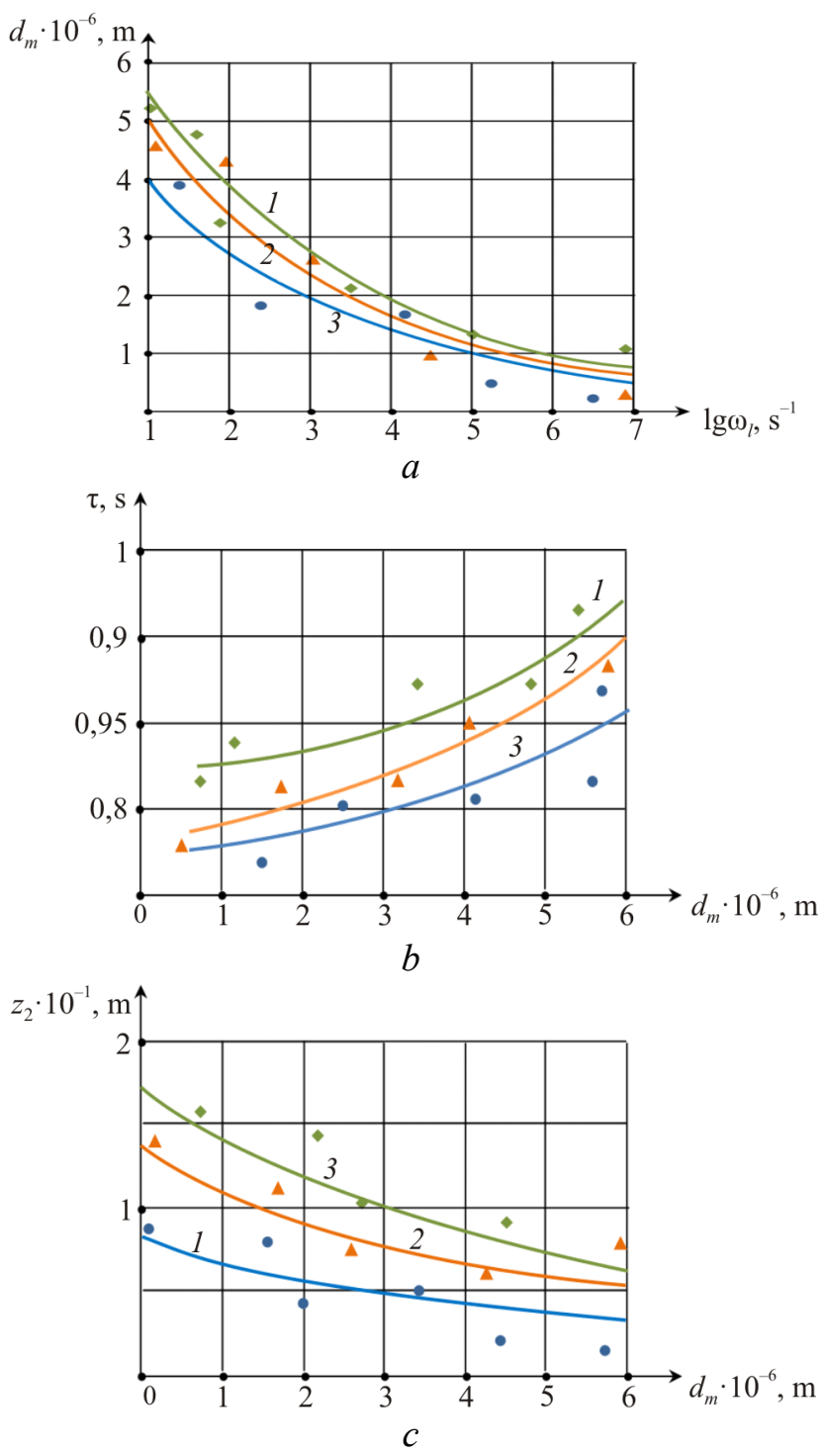

$\Delta z \cdot 10^{-2}, \mathrm{~m}$

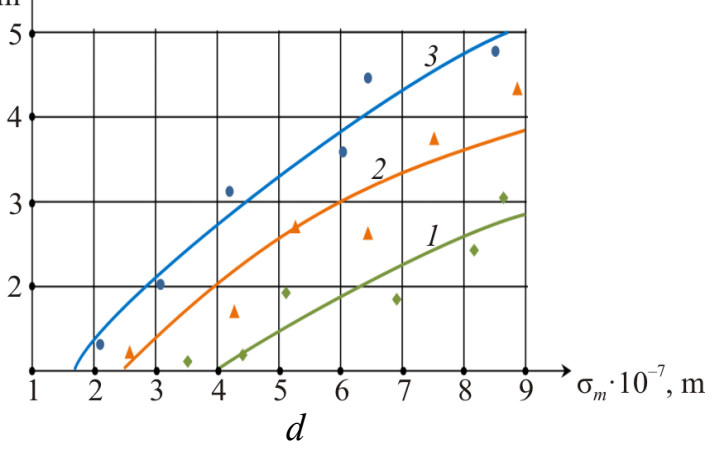

Fig. 4. Depencency: $a$ - median wetting diameter of TMF component particles on liquid drops rotation rate during hydrovortex classification; $b$ - average relaxation time of liquid drop with integrated TMF component particle on median diameter $\left(\operatorname{Re}_{0}=40\right) ; c-$ input classification collector coordinates on median diameter of classification particles; $d$ - width of input classification collector on dispersion of particle median size $\left(d_{m}=2 \cdot 10^{-6} \mathrm{~m}\right) ; 1$ - coal; 2 - silicon oxide; 3 - aluminum oxide 
Figure 4 shows the results of experimental studies and their comparison to the calculation results based on the proposed mathematical model.

According to Figure 4, the experimental research data compared to the calculation based on the proposed mathematical model confirm an effective control over the minimum diameter of the absorbed hydrophobic TMF particles using the liquid drop rotation rate in the process of hydrovortex classification.

The experimental research data, compared to the calculation based on the proposed mathematical model, shown in Figure 4, $b$, confirm an increased relaxation time in the process of hydrovortex classification of particles with large median size, which is one of the key factors enabling the classification of micro and nanoparticles by dispersion of their median diameters.

The result shown in Figure 4, $c, d$ suggests that the position and size of the input classification collector depend on median diameter and dispersion of the TMF micro and nanoparticles being classified. An increased median diameter monotonously lowers the input classification collector along the plane of the hydrovortex aerator nozzles and reduces its length. Therefore, the less is the median diameter of micro and nanoparticles to be classified, the closer is the input classification collector position in the plane of hydrovortex nozzles. Smaller median size dispersion of the target micro and nanoparticles requires reducing the length of one classification collector.

The experimental studies of the Venturi hydrovortex classifier performed in SMK-TEST have confirmed repeatability with the proposed mathematical model to the extent sufficient for engineering calculations.

\section{Conclusion}

1. Controlling the liquid drop rotation rate in the process of hydrovortex classification enables effective separation of microparticles with nominal diameter from $(0.5-5.0) \cdot 10^{-6} \mathrm{~m}$ into fractions with predetermined dispersion.

2. In the hydrovortex classification, the time of relaxation for liquid drops with integrated TMF micro and nanoparticles depends on median size. This is the main determinant factor in achieving high classification effectiveness by controlling the inertial force dynamics of the unsteady hydrovortex motion of the 'liquid drop - TMF microparticle' disperse system.

3. The Venturi classifier geometrical parameters are determined by the necessary performance and energy characteristics of the hydrovortex aerator.

\section{References}

1. Makarov V.N., Davydov S.Ia. Teoreticheskie osnovy povysheniia effektivnosti ventiliatsii $\mathrm{v}$ tekhnologicheskikh protsessakh na promyshlennykh predpriiatiiakh [Theoretical basis for the in-process ventilation systems efficiency increasing at industrial enterprises]. Novye ogneupory, 2015, no.2, pp.59-63. DOI: 10.17073/1683-4518-2015-2-59-63

2. Makarov V.N., Davydov S.Ya. Theoretical basis for increasing ventilation efficiency in technological processes at industrial enterprises. Refractories and Industrial Ceramics, 2015, vol.56, iss.1, pp.103-106. DOI: $10.1007 / \mathrm{s} 11148-015-9791-7$

3. Davydov S.Ia. Ispolzovanie kipiashchego sloia dlia energosberegaiushchego pnevmopodema melkodispersnoi pyli [Use of a fluidized bed for energy-saving pneumatic lifting of fine dust]. Novye ogneupory, 2012, no.9, pp.17-22.

4. Davydov S.Ia., Apakashev R.A., Kiiko V.S. et al. Rezultaty obsledovaniia skhemy pnevmotransporta izvestkovoi pyli, soderzhashchei nanochastitsy, na OAO "Serovskii zavod ferrosplavov" [The results of the inspection of the scheme of pneumatic transport of lime dust containing nanoparticles at OJSC "Serov Ferroalloy Plant"]. Novye ogneupory, 2015, no.11, pp.17-22. DOI: $10.17073 / 1683-4518-2015-11-17-22$

5. Davydov S.Ia., Zobnin B.B., Apakashev R.A., Vozhegov A.V., Valiev N.G. Ustroistvo dlia pnevmopodema sypuchikh materialov, soderzhashchikh nanochastitsy [Device for pneumatic lifting of bulk materials contain- 
ing nanoparticles]: patent 2613980 Russian Federation, 2017.

6. Davydov S.Ia., Semin A.N. Energosberegaiushchee oborudovanie pnevmaticheskogo transporta: vchera, segodnia, zavtra: teoriia, raschet, issledovaniia, proizvodstvo [Energysaving equipment for pneumatic transport: yesterday, today, tomorrow: theory, calculation, research, production]. Moscow, Kadrovyi rezerv, 2016, 472 p.

7. Gordeev Iu.I., Abkarian A.K., Zeer G.M. et al. Vliianie dobavok legiruiushchikh keramicheskikh nanochastits na strukturnye parametry i svoistva tverdykh splavov [Effect of alloying additives of the ceramic nanoparticles on the structural parameters and properties of hard alloys]. Vestnik Sibirskogo gosudarstvennogo aerokosmicheskogo universiteta imeni akademika M.F. Reshetneva, 2013, no.3, pp.174-181.

8. Davydov S.Ia., Kosarev N.P., Valiev N.G. et al. Ispolzovanie glinozemistoi pyli pechei kaltsinatsii gidroksida aliuminiia [The application of aluminous dust after aluminum hydroxide kiln calcining]. Novye ogneupory, 2013, no.4, pp.52-58. DOI: 10.17073/1683-4518-2013-4-52-58

9. Davydov S.Ya., Apakashev R.A., Korukov V.N. Utilization of alumina calcining furnace dust containing nanoparticles. Refractories and Industrial Ceramics, 2014, vol.55, no.4, pp.291-294. DOI: $10.1007 / \mathrm{s} 11148-014-9711-2$

10. Kovshov S.V., Kovshov V.P. Chemical technology of dust suppression on open-pit mines. International Journal of Ecology and Development, 2015, 30(3), pp.55-67.

11. Nikulin A., Kovshov S., Mráčková E. Recycling of liquid and solid waste into fuel pellets and briquettes. Production Management and Engineering Sciences, 2016, pp. 223-227. DOI: $10.9774 /$ GLEAF.9781315673790_41

12. Gendler S.G., Kovshov S.V. Estimation and reduction of mining-induced damage of the environment and work area air in mining and processing of mineral stuff for the building industry. Eurasian Mining, 2016, 3, pp.3-12. DOI: $10.17580 / \mathrm{em} .2016 .01 .08$

13. Kovshov S.V., Kovshov V.P. Aerotechnogenic evaluation of the drilling rig operator workplace at the open-pit coal mine. Ecology, Environment and Conservation, 2017, 23 (2), pp.897-902.

14. Cecala A.B., Andrew D. Dust control handbook for industrials minerals mining and processing. Office of Mine safety and Health Research, 2012, p.159.

15. Davydov S.Ia., Apakashev R.A., Koriukov V.N. Utilizatsiia pyli pechei kaltsinatsii glinozema, soderzhashchei nanochastitsy [The recycling of the alumina calciner kiln dust containing nanoparticles]. Novye ogneupory, 2014, no.8, pp.10-13. DOI: $10.17073 / 1683-4518-2014-8-10-13$

16. Makarov V.N., Potapov V.Ya., Davydov S.Ya., Makarov N.V. A method of additive aerodynamic calculation of the friction gear classification block. Refractions and Industrial Ceramics, 2017, vol. 38, no.3, pp.288-292. DOI: $10.1007 / \mathrm{s} 11148-017-0098-8$

17. Davydov S.Ya., Apakashev R.A., Korukov V.N. Capturing nanoparticles in alumina production. Refractories and Industrial Ceramics, 2016, vol. 57, no.1, pp.9-12. DOI: $10.1007 / \mathrm{S} 11148-016-99-17-6$

18. Lyashenko V.I., Gurin A., Topolniy F.F., Taran N.A. Justification of environmental technologies and means for dust control of tailing dumps surfaces of hydrometallurgical production and concentrating plants. Metallurgical and mining industry, 2017, no.4, pp.8-17.

19. Davydov S.Ya., Apakashev R.A., Korukov V.N. Utilization of alumina calcining furnace dust containing nanoparticles. Refractories and Industrial Ceramics, 2014, vol.55, iss.4, pp.291-294. DOI: $10.1007 / \mathrm{s} 11148-014-9711-2$

20. Davydov S.Ia., Apakashev R.A., Koriukov V.N. Ulavlivanie nanorazmernoi fraktsii chastits glinozemnogo proizvodstva [The collection of nanoscale particles in alumina production]. Novye ogneupory, 2016, no.2, pp.12-15. DOI: 10.17073/1683-4518-2016-2-12-15

21. Davydov S.Ia., Apakashev R.A., Kiiko V.S. et al. Rezultaty obsledovaniia izvestkovoi pyli, soderzhashchei nanochastitsy, na OAO "Serovskii zavod ferrosplavov" [The results of the examination of calcareous dust containing nanoparticles 
at the Serov Ferroalloy Plant OJSC]. Novye ogneupory, 2015, no.3, pp.20-21. DOI: 10.17073/1683-4518-2015-11-17-22

22. Novakovskiy N.S., Bautin S.P. Numerical simulation of shock-free strong compression of 1d gas layer. Journal of Physics: Conference Series, 2017, vol.894, no.1, pp.12067. DOI: $10.1088 / 1742-6596 / 894 / 1 / 012067$

23. Alymenko N.I., Kamenskikh A.A., Nikolaev A.V., Petrov A.I. Numerical modeling of heat and mass transfer during hot and cool air mixing in a supplyshaft in underground mine. Eurasian mining, 2016, no.2, pp.45-47. DOI: $10.17580 / \mathrm{em} .2016 .02 .11$

24. Korshunov G.I., Kovshov S.V., Safina A.M. Dust control methods in open-pit mining. Current state of physical \& chemical research. Ecology, Environment and Conservation, 2017, vol.23, iss.2, pp.883-889.

25. Kovshov S., Nikulin A., Kovshov V., Mračková E. Application of equipment for aerological researching of characteristics of wood dust. Acta Facultatis Xylologiae, 2015, 57(1), pp.111-118.

26. Fenchenko V.N., Kravchenko O.V., Momot V.I. Dvizhenie zariazhennykh dielektricheskikh melkodispersnykh chastits $\mathrm{V}$ apparatakh elektronno-ionnoi tekhnologii [The movement of charged dielectric fine particles in the apparatus of electron-ion technology]. Vostochno-Evropeiskii zhurnal peredovykh tekhnologii, 2012, no.3/10, pp.50-53.

27. Program evaluation and information resources, standardized information system. Department of Labor, Mine Safety and Health Administration. Arlington, 2009.

28. Khanamirova A.A., Apresian L.P., Adimosian A.R. Poluchenie maloshchelochnogo vysokodispersnogo korunda iz glinozemnoi pyli [Preparation of low-alkali high-dispersity corundum from the alumina dust]. Khimicheskii zhurnal Armenii, 2008, no.1, pp.37-44.

29. Makarov V.N., Makarov N.V., Potapov V.V., Gorshkova E.M. Perspektivnyi sposob povysheniia effektivnosti vysokonapornogo gidroobespylivaniia A promising method of high-pressure hydro-dusting efficiency increasing]. Vestnik Zabaikalskogo gosudarstvennogo universiteta, 2018, vol.24, no.5, pp.13-20. DOI: $10.21209 / 2227-9245-2018-24-5-13-20$

30. Kosarev N.P., Makarov V.N., Makarov N.V., Ugolnikov A.V., Lifanov A.V. Effective localization of coal dust explosions using hydro vortex coagulation. Perm Journal of Petroleum and Mining Engineering, 2018, vol.18, no.2, pp.178-189. DOI: $10.15593 / 2224-9923 / 2018.4 .7$

31. Frolov A.V., Telegin V.A., Sechkerev Iu.A. Osnovy gidroobespylivaniia [Water dedusting basics]. Bezopasnost zhiznedeiatelnosti, 2007, no.10, pp.1-24.

32. Wu D., Yin K., Yin Q., Zhang X., Cheng J., Ge D., Zhang P. Reverse circulation drilling method based on a supersonic nozzle for dust control. Applied Sciences (Switzerland), 2017, vol.7, no.1, pp.5-20. DOI: 10.3390/APP7010005

33. Listak J.M., Reed W.R. Water separator shows potential for reducing respirable dust generated on smalldiameter rotary blasthole drills. Int $J$ Min Reclam Environ, 2007, no.3, pp.160-172. DOI: $10.1080 / 17480930601176846$

34. Makarov V.N., Makarov N.V., Plotnikov N.S., Potapov V.V. Matematicheskoe modelirovanie vikhrevogo gidroobespylivaniia na gorno-obogatitelnykh predpriiatiiakh [Mathematical modeling of vortex hydridedusting at mining and processing plants]. Gornyi informatsionno-analiticheskii biulleten, 2018, no.4, pp.210-217. DOI: 10.25018/0236-1493-2018-4-0-210-217

35. Bautin S.G., Krutova I.Y., Obukhov A.G. Twisting of a fire vortex subject to gravity and coriolis forces. High temperature, 2015, vol.53, no.6, pp.928-930. DOI: $10.1134 / \mathrm{S} 0018151 \mathrm{X} 1505003 \mathrm{X}$

36. Bautin S.P. Mathematical simulation of the vertical part of an upward swirling flow. High temperature, 2014, vol.52, no.2, pp.259-263. DOI: $10.1134 / \mathrm{S} 0018151 \mathrm{X} 14020035$

37. Loitsianskii L.G. Mekhanika zhidkosti i gaza [Fluid and gas mechanics]. Moscow, Drofa, 2003, 840 p.

38. Fuks N.A. Mekhanika aerozolei [Aerosol mechanics]. Moscow, Izdatelstvo AN SSSR, $1955,352 \mathrm{p}$. 
39. Venikov V.A. Teoriia podobiia i modelirovaniia primenitelno $\mathrm{k}$ zadacham elektroenergetiki [The theory of similarity and modeling in relation to the problems of the electric power industry]. Moscow, Librokom, 2014, 439 p.

\section{Библиографический список}

1. Макаров В.Н., Давыдов С.Я. Теоретические основы повышения эффективности вентиляции в технологических процессах на промышленных предприятиях // Новые огнеупоры. - 2015. - № 2. - C. 59-63. DOI: $10.17073 / 1683-4518-2015-2-59-63$

2. Makarov V.N., Davydov S.Ya. Theoretical basis for increasing ventilation efficiency in technological processes at industrial enterprises // Refractories and Industrial Ceramics. - 2015. - Vol. 56, iss. 1. - P. 103-106. DOI: $10.1007 / \mathrm{s} 11148-015-9791-7$

3. Давыдов С.Я. Использование кипящего слоя для энергосберегающего пневмоподъема мелкодисперсной пыли // Новые огнеупоры. 2012. - № 9. - С. 17-22.

4. Результаты обследования схемы пневмотранспорта известковой пыли, содержащей наночастицы, на ОАО «Серовский завод ферросплавов» / С.Я. Давыдов, Р.А. Апакашев, В.С. Кийко [и др.] // Новые огнеупоры. - 2015. - № 11. - C. 17-22. DOI: 10.17073/1683-4518-2015-11-17-22

5. Устройство для пневмоподъема сыпучих материалов, содержащих наночастицы: пат. 2613980 Рос. Федерация / Давыдов С.Я., Зобнин Б.Б., Апакашев Р.А., Вожегов А.В., Валиев Н.Г. - № 2015144394; зявл. 15.10.2015; опубл. 22.03.2017. - Бюл. № 9.

6. Давыдов С.Я., Семин А.Н. Энергосберегающее оборудование пневматического транспорта: вчера, сегодня, завтра: теория, расчет, исследования, производство. М.: Кадровый резерв, 2016. - 472 с.

7. Влияние добавок легирующих керамических наночастиц на структурные параметры и свойства твердых сплавов / Ю.И. Гордеев, А.К. Абкарян, Г.М. Зеер [и др.] // Вестник Сибирского государственного аэрокосмического университета им. академика М.Ф. Решетнева. 2013. - № 3. - С. 174-181.

8. Использование глиноземистой пыли печей кальцинации гидроксида алюминия / С.Я. Давыдов, Н.П. Косарев, Н.Г. Валиев [и др.] //
Новые огнеупоры. - 2013. - № 4. - С. 52-58. DOI: 10.17073/1683-4518-2013-4-52-58

9. Davydov S.Ya., Apakashev R.A., Korukov V.N. Utilization of alumina calcining furnace dust containing nanoparticles // Refractories and Industrial Ceramics. - 2014. - Vol. 55, № 4. P. 291-294. DOI: 10.1007/s11148-014-9711-2

10. Kovshov S.V., Kovshov V.P. Chemical technology of dust suppression on open-pit mines // International Journal of Ecology and Development. 2015. - 30 (3). - P. 55-67.

11. Nikulin A., Kovshov S., Mráčková E. Recycling of liquid and solid waste into fuel pellets and briquettes // Production Management and Engineering Sciences Scientific Publication of the International Conference on Engineering Science and Production Management, ESPM 2015. - 2016. - P. 223-228. DOI: 10.9774/GLEAF.9781315673790_41

12. Gendler S.G., Kovshov S.V. Estimation and reduction of mining-induced damage of the environment and work area air in mining and processing of mineral stuff for the building industry // Eurasian Mining. - 2016. - 3. P. 3-12. DOI: 10.17580/em.2016.01.08

13. Kovshov S.V., Kovshov V.P. Aerotechnogenic evaluation of the drilling rig operator workplace at the open-pit coal mine // Ecology, Environment and Conservation. - 2017. - 23 (2). P. 897-902.

14. Cecala A.B., Andrew D. Dust control handbook for industrials minerals mining and processing / Office of Mine safety and Health Research. - 2012. - P. 159.

15. Давыдов С.Я., Апакашев Р.А., Корюков В.Н. Утилизация пыли печей кальцинации глинозема, содержащей наночастицы // Новые огнеупоры. - 2014. - № 8. - C. 10-13. DOI: $10.17073 / 1683-4518-2014-8-10-13$

16. A method of additive aerodynamic calculation of the friction gear classification block / V.N. Makarov, V.Ya. Potapov, S.Ya. Davydov, N.V. Makarov // Refractions and 
Industrial Ceramics. - 2017. - Vol. 38, № 3. P. 288-292. DOI: $10.1007 / \mathrm{s} 11148-017-0098-8$

17. Davydov S.Ya., Apakashev R.A., Korukov V.N. Capturing nanoparticles in alumina production // Refractories and Industrial Ceramics. - 2016. - Vol. 57, № 1. - P. 9-12. DOI: $10.1007 / \mathrm{S} 11148-016-99-17-6$

18. Justification of environmental technologies and means for dust control of tailing dumps surfaces of hydrometallurgical production and concentrating plants / V.I. Lyashenko, A. Gurin, F.F. Topolniy, N.A. Taran // Metallurgical and mining industry. 2017. - № 4. - P. 8-17.

19. Davydov S.Ya., Apakashev R.A., Korukov V.N. Utilization of alumina calcining furnace dust containing nanoparticles // Refractories and Industrial Ceramics. - 2014. - Vol. 55, № 4. P. 291-294. DOI: 10.1007/s11148-014-9711-2

20. Давыдов С.Я., Апакашев Р.А., Корюков В.Н. Улавливание наноразмерной фракции частиц глиноземного производства // Новые огнеупоры. - 2016. - № 2. - С. 12-15. DOI: $10.17073 / 1683-4518-2016-2-12-15$

21. Результаты обследования известковой пыли, содержащей наночастицы, на ОАО «Серовский завод ферросплавов» / С.Я. Давыдов, P.А. Апакашев, В.С. Кийко [и др.] // Новые огнеупоры. - 2015. - № 3. - C. 20-21. DOI: $10.17073 / 1683-4518-2015-11-17-22$

22. Novakovskiy N.S., Bautin S.P. Numerical simulation of shock-free strong compression of 1d gas layer // Journal of Physics: Conference Series. - 2017. - Vol. 894, № 1 - P. 12067 DOI: $10.1088 / 1742-6596 / 894 / 1 / 012067$

23. Numerical modeling of heat and mass transfer during hot and cool air mixing in a supplyshaft in underground mine / N.I. Alymenko, A.A. Kamenskikh, A.V. Nikolaev, A.I. Petrov // Eurasian mining. - 2016. - № 2. - P. 45-47. DOI: $10.17580 / \mathrm{em} .2016 .02 .11$

24. Korshunov G.I., Kovshov S.V., Safina A.M. Dust control methods in open-pit mining. Current state of physical \& chemical research // Ecology, Environment and Conservation. - 2017. - Vol. 23, iss. 2. - P. 883-889.

25. Application of equipment for aerological researching of characteristics of wood dust / S. Kovshov, A. Nikulin, V. Kovshov, E. Mračková //
Acta Facultatis Xylologiae. - 2015. - 57(1). P. 111-118.

26. Фенченко В.Н., Кравченко О.В., Момот В.И. Движение заряженных диэлектрических мелкодисперсных частиц в аппаратах электронноионной технологии // Восточно-Европейский журнал передовых технологий. - 2012. - № 3/10. C. $50-53$.

27. Program evaluation and information resources, standardized information system / Department of Labor, Mine Safety and Health Administration. - Arlington, 2009.

28. Ханамирова А.А., Апресян Л.П., Адимосян А.Р. Получение малощелочного высокодисперсного корунда из глиноземной пыли // Химический журнал Армении. - 2008. № 1. - С. 37-44.

29. Перспективный способ повышения эффективности высоконапорного гидрообеспыливания / В.Н. Макаров, Н.В. Макаров, В.В. Потапов, Э.М. Горшкова // Вестник Забайкальского государственного университета. - 2018. - Т. 24, № 5. - С. 13-20. DOI: $10.21209 / 2227-9245-2018-24-5-13-20$

30. Эффективная локализация взрывов угольной пыли с использованием гидровихревой коагуляции / В.Н. Макаров, Н.П. Косарев, Н.В. Макаров, А.В. Угольников, А.В. Лифанов // Вестник Пермского национального исследовательского политехнического университета. Геология. Нефтегазовое и горное дело. - 2018. - Т. 18, № 2. C. $178-189$. DOI: $10.15593 / 2224-9923 / 2018.4 .7$

31. Фролов А.В., Телегин В.А., Сечкерев Ю.А. Основы гидрообеспыливания // Безопасность жизнедеятельности. - 2007. - № 10. C. 1-24.

32. Reverse circulation drilling method based on a supersonic nozzle for dust control / D. Wu, K. Yin, Q. Yin, X. Zhang, J. Cheng, D. Ge, P. Zhang // Applied Sciences (Switzerland). - 2017. - T. 7, № 1. - P. 5-20. DOI: 10.3390/APP7010005

33. Listak J.M., Reed W.R. Water separator shows potential for reducing respirable dust generated on small-diameter rotary blasthole drills // Int J Min Reclam Environ. - 2007. - № 3. P. 160-172. DOI: $10.1080 / 17480930601176846$

34. Математическое моделирование вихревого гидрообеспыливания на горно-обогатительных предприятиях / В.Н. Макаров, 
Н.В. Макаров, Н.С. Плотников, В.В. Потапов // Горный информационно-аналитический бюллетень. - 2018. - № 4. - С. 210-217. DOI: 10.25018/0236-1493-2018-4-0-210-217

35. Bautin S.G., Krutova I.Y., Obukhov A.G. Twisting of a fire vortex subject to gravity and coriolis forces // High temperature. 2015. - Vol. 53, № 6. - P. 928-930. DOI: 10.1134/S0018151X1505003X

36. Bautin S.P. Mathematical simulation of the vertical part of an upward swirling flow // High temperature. - 2014. - Vol. 52, № 2. - P. 259-263. DOI: $10.1134 / \mathrm{S} 0018151 \mathrm{X} 14020035$

37. Лойцянский Л.Г. Механика жидкости и газа: учеб. для вузов. - 7-е изд., испр. М.: Дрофа, 2003. -840 с.

38. Фукс Н.А. Механика аэрозолей. М.: Изд-во АН СССР, 1955. - 352 с.

39. Веников В.А. Теория подобия и моделирования применительно к задачам электроэнергетики: учеб. для вузов. - 4-е изд. М.: Либроком, 2014. - 439 с.

Please cite this article in English as:

Kosarev N.P., Makarov V.N., Ugolnikov A.V., Makarov N.V., Lifanov A.V. The effective method for hydrovortex classification of finely dispersed technogenic mineral waste in the mining and metals industry. Perm Journal of Petroleum and Mining Engineering, 2019, vol.19, no.4, pp.388-400. DOI: 10.15593/2224-9923/2019.4.7

Просьба ссылаться на эту статью в русскоязычных источниках следующим образом:

Эффективный способ гидровихревой классификации тонкодисперсных техногенных минеральных отходов в горнометаллургическом комплексе / Н.П. Косарев, В.Н. Макаров, А.В. Угольников, Н.В. Макаров, А.В. Лифанов // Вестник Пермского национального исследовательского политехнического университета. Геология. Нефтегазовое и горное дело. 2019. - T.19, №4. - C.388-400. DOI: 10.15593/2224-9923/2019.4.7 